\title{
"On Hallowed Ground": St. Roch, Sovereignty, and the 1944 Northwest Passage Transit
}

\section{Peter Kikkert and P. Whitney Lackenbauer}

En 1944, Henry Asbjørn Larsen et l'équipage du St-Roch ont achevé la première traversée en une seule saison du passage du Nord-Ouest, ayant parcouru 11740 kilomètres en 86 jours. Le voyage a également marqué la première traversée réussie de la route vers le nord du passage du NordOuest. Mais pourquoi le gouvernement canadien a-t-il décidé de dépêcher le St-Roch dans l'Extrême-Arctique en plein milieu de la Seconde Guerre mondiale? Pourquoi le navire a-t-il visité les îles inhabitées de la partie nord de l'archipel arctique, où il n'y avait personne à surveiller? En abordant ces questions, le présent article situe le voyage du St-Roch dans l'histoire plus générale de la souveraineté canadienne dans l'Arctique.

At noon on 28 August 1944, the RCMP schooner St. Roch anchored at the entrance of Winter Harbour, Melville Island. The previous days had brought blinding snow, thick fog, and worsening ice conditions as the ship maneuvered through the northerly route of the Northwest Passage. Now "very thick weather" kept the crew from sailing into the cove. When the conditions improved a few hours later, the ship moved inside Winter Harbour, carefully dodging the "large pieces of heavy ice" that crowded its waters. Led by their captain, Staff Sergeant Henry Asbjørn Larsen, the crew rowed ashore to visit one of the most famous sites on Canada's high Arctic islands: Parry's Rock.

In 1819, the Royal Navy's William Edward Parry had taken HMS Hecla and HMS Griper through unusually ice-free waters in the channel that now bears

The Northern Mariner / Le marin du nord, XXIX, No. 3 (Fall 2019), 213-232 
his name (Parry Channel), achieving a furthest west record in the quest for the Northwest Passage. Parry and his men became the first Europeans to visit Melville Island, where they were frozen in for ten months in the anchorage that Parry named Winter Harbour. While there, Parry had left a clear sign of his expedition's presence, carving Hecla and Griper into a large sandstone rock, along with the names of several crew members. ${ }^{1}$

As Larsen and his men surveyed Parry's Rock, they saw another milestone in the history of exploration in the Arctic archipelago - the plaque of JosephElzéar Bernier. Between 1904 and 1911, Bernier had made extensive governmentsponsored voyages into the waters of the archipelago to intercept and impose licenses on foreign whalers, collect customs duties, and conduct geographical research. He also performed ceremonies of possession on northern islands to reinforce Canada's sovereignty. In 1908-1909, Bernier decided to follow Parry's example and overwinter at Winter Harbour. On 1 July 1909, Bernier marched his entire crew to Parry's Rock, where they installed a large copper plate which took possession for "the Dominion of Canada, of the whole Arctic Archipelago lying to the north of America from long. 60 W. to 141 W., up to lat. 90 North."2

During their pilgrimage to Parry's Rock, Larsen also took his men to a tiny, dilapidated shack that stood about a mile away. Bernier had constructed the hut as a storehouse when he re-visited Winter Harbour during his 1910 expedition. He had filled the hut with food and equipment in case any other expedition that visited Melville Island ever required assistance. When Larsen inspected the storehouse, he noted that it now stood empty, save for a few rusty tins of flour and tea - its supplies used by the members of the Canadian Arctic Expedition who had visited the spot in 1916 and 1917. The leader of that expedition, Vilhjalmur Sefansson, insisted on visiting Parry's Rock because it was the "one spot among the Canadian arctic islands that has been really well located," allowing him to reinforce the "certainty of [the] longitudes" taken by his expedition. ${ }^{3}$ During the visits, Stefansson's hungry party had feasted on the pilot bread, flour, port, honey, and preserved fruit left by Bernier, and used the iron shoeing for their sled.

As the crew surveyed the plundered hut, a bottle hanging from the rafters caught their attention. It contained a written notice from RCMP Inspector Alfred Herbert Joy who, from March to May 1929, with another constable, the Inughuit hunter and guide Nukappiannguaq, and two dog teams, travelled 1700 miles from Dundas Harbour on Devon Island in the eastern archipelago, to Winter Harbour

\footnotetext{
1 See, for instance, Glyn Williams, Arctic Labyrinth: The Quest for the Northwest Passage (Toronto: Viking Canada, 2009), 193. Parry's Rock stands three metres high and five and a half metres long.

2 On Bernier's voyages, see Yolande Dorion-Robitaille, Captain JE Bernier's contribution to Canadian sovereignty in the Arctic (Ottawa: Indian and Northern Affairs, 1978); Janice Cavell, "As far as 90 north': Joseph Elzéar Bernier's 1907 and 1909 sovereignty claims," Polar Record 46:239 (2010), 372-76; Alan MacEachern, “J.E. Bernier's Claims to Fame," Scientia Canadensis 33:2 (2010), 43-73.

3 Vilhjalmur Stefansson, "The Activities of the Canadian Arctic Expedition from October, 1916, to April, 1918," Geographical Review 6:4 (Oct., 1918), 354-369.
} 
on Melville Island, covering Lougheed, King Christian, Ellef Ringnes, Cornwall, and Axel Heiberg Islands along the way. ${ }^{4}$ In Larsen's account of his 1944 voyage, he described Joy's effort as "perhaps the longest and most famous patrol in Arctic history." 5

From Parry's Rock, to Bernier's hut, to Stefansson's waste, to Joy's bottle Larsen and his crew marched through the annals of British and Canadian Arctic exploration during their short stay on Melville Island. Larsen called the cairns, caches, memorials, and graves that littered the northern islands "the keystone of Canada's Arctic sovereignty." ${ }^{6}$ By visiting these sites and literally touching these "keystones," Larsen was reaffirming the connection between past and present British and Canadian activities in the Arctic archipelago. Now, as their last act on Melville Island, his crew joined their predecessors by leaving a record of their own visit at Parry's Rock. Larsen then guided his ship out of Winter Harbour and into the icy waters of Viscount Melville Sound, ${ }^{7}$ before heading southwest into "waters never before traversed by any vessel, the eastern entrance to McClure Strait." The crew of St. Roch were eager to make some history of their own.

The activities of Larsen and his crew at Winter Harbour and Parry's Rock highlight the main purpose of their voyage: sovereignty. The 1944 voyage of St. Roch through the Northwest Passage has received little attention compared to the ship's famous 1940-1942 west-east transit, the secret orders and objectives for which have inspired considerable commentary from Arctic scholars. ${ }^{8}$ While several authors, including Larsen, have provided narratives of the 1944 transit and indicated that sovereignty concerns were the primary motivation for the expedition, ${ }^{9}$ little additional detail has been provided on the government's rationale for sending St. Roch back through the Passage. Why, during the height of the Second World War, did the government dispatch Larsen and his crew to the uninhabited northern half of the Arctic archipelago, where there was no one to police or administer? The notoriety gained for being the first to transit the northern

\footnotetext{
${ }_{4}$ William R. Morrison, Showing the Flag: The Mounted Police and Canadian Sovereignty in the North, 1894-1925 (Vancouver: University of British Columbia Press, 1985), 170.

${ }^{5}$ Henry A. Larsen, The North-West Passage 1940-1942 and 1944: The Famous Voyages of the Royal Canadian Mounted Police Schooner “St. Roch” (Ottawa: Queen's Printer, 1958), 44.

6 Henry Larsen, "Our Return Voyage through the North-West Passage," RCMP Quarterly 10:4 (1945), 320.

${ }^{7}$ Larsen, North-West Passage, 44.

${ }^{8}$ See, for instance, Shelagh D. Grant, "Why the St. Roch? Why the Northwest Passage? Why 1940 ? New Answers to Old Questions," Arctic 46:1 (March 1993), 82-87; Gordon W. Smith, A Historical and Legal Study of Sovereignty in the Canadian North: Terrestrial Sovereignty, 1870-1939, ed. P. Whitney Lackenbauer (Calgary: University of Calgary Press, 2014). See also, G.J. Tranter, Plowing the Arctic: Being an account of the voyage of the R.C.M.P. 'St. Roch' through the North West Passage from West to East (Toronto: Longmans, Green, 1945).

9 Larsen, North-West Passage; Larsen, "Return Voyage": 298-320; Doreen Larsen Riedel, "The More Northerly Route: Looking Back 70 Years," Argonauta 32:1 (Winter 2015), 5-18; Janice Cavell, "Introduction," in Documents on Canadian External Relations (DCER): The Arctic, 1874-1949 (Ottawa: Global Affairs Canada, 2016), xxxiv-xxxv.
} 
route of the Passage no doubt influenced the decision, but concern over American intentions in the high Arctic, how officials understood the rules and requirements of territorial acquisition, and the influence of British policies in the Antarctic all provided impetus for the expedition and dictated its objectives.

\section{Sovereignty, the RCMP, and the Construction of St. Roch}

From the moment St. Roch was launched in 1928, sovereignty concerns shaped its mandate and mission, and never more so than during its historic 1944 voyage. Canada's lingering concerns about its sovereignty in the high Arctic are well documented in existing scholarship. In 1880, Britain gifted to Canada whatever territories or territorial rights it had in the Arctic archipelago. The completeness of Britain's own title at that time, and the extent of its territories, remained uncertain. Over the next two decades, Canada did little to consolidate its administrative or practical control over its new territorial gift - its claim continued to rest on British acts of discovery and little more. At the turn of the twentieth century, however, the presence of foreign explorers in the Arctic archipelago and the expansion of American whaling operations into the Beaufort Sea finally forced the Canadian government to consider the strength of its sovereignty. Canada's response to these activities was to embark "on a long range, though relatively low-key, program of finding out more about her northern territories, securing Canadian sovereignty, and advancing the frontiers of scientific knowledge."10 To extend Canada's regulation and control over the region, the North-West Mounted Police (NWMP) established posts on Herschel Island in the Beaufort Sea and Cape Fullerton on the northwest shore of Hudson Bay in 1903. Following the footsteps of earlier Canadian northern voyages led by William Wakeham and Albert Peter Low, Bernier began his patrols of the waters of Hudson Bay and the Arctic islands. Between 1913 and 1918, the government also sponsored Vilhjalmur Stefansson's two-pronged Canadian Arctic Expedition in the western Arctic, which explored and took possession of several islands for Canada, adding several thousand square kilometres to the country's territory, while clarifying cartographically ambiguous territory such as Prince Patrick Island. ${ }^{11}$

Concurrent to the government's efforts to show the flag and assert its control in the Arctic, Senator Pascal Poirier offered an easier and far more definite method for securing sovereignty: the sector principle. In a speech to his Senate colleagues in Ottawa, Poirier advised that:

\footnotetext{
10 Richard Diubaldo, Stefansson and the Canadian Arctic (Montreal \& Kingston: McGill-Queen's University Press, 1978), 7.

11 See, for example, Morrison, Showing the Flag; Shelagh Grant, Polar Imperative: A History of Sovereignty in North America (Vancouver: Douglas \& McIntyre, 2010); Peter Kikkert and P. Whitney Lackenbauer, eds., Legal Appraisals of Canada's Arctic Sovereignty: Key Documents, 1904-58, Documents on Canadian Arctic Sovereignty and Security (DCASS) No. 2 (Calgary: Centre for Military and Strategic Studies, 2014), and Smith, Historical and Legal Study of Sovereignty.
} 


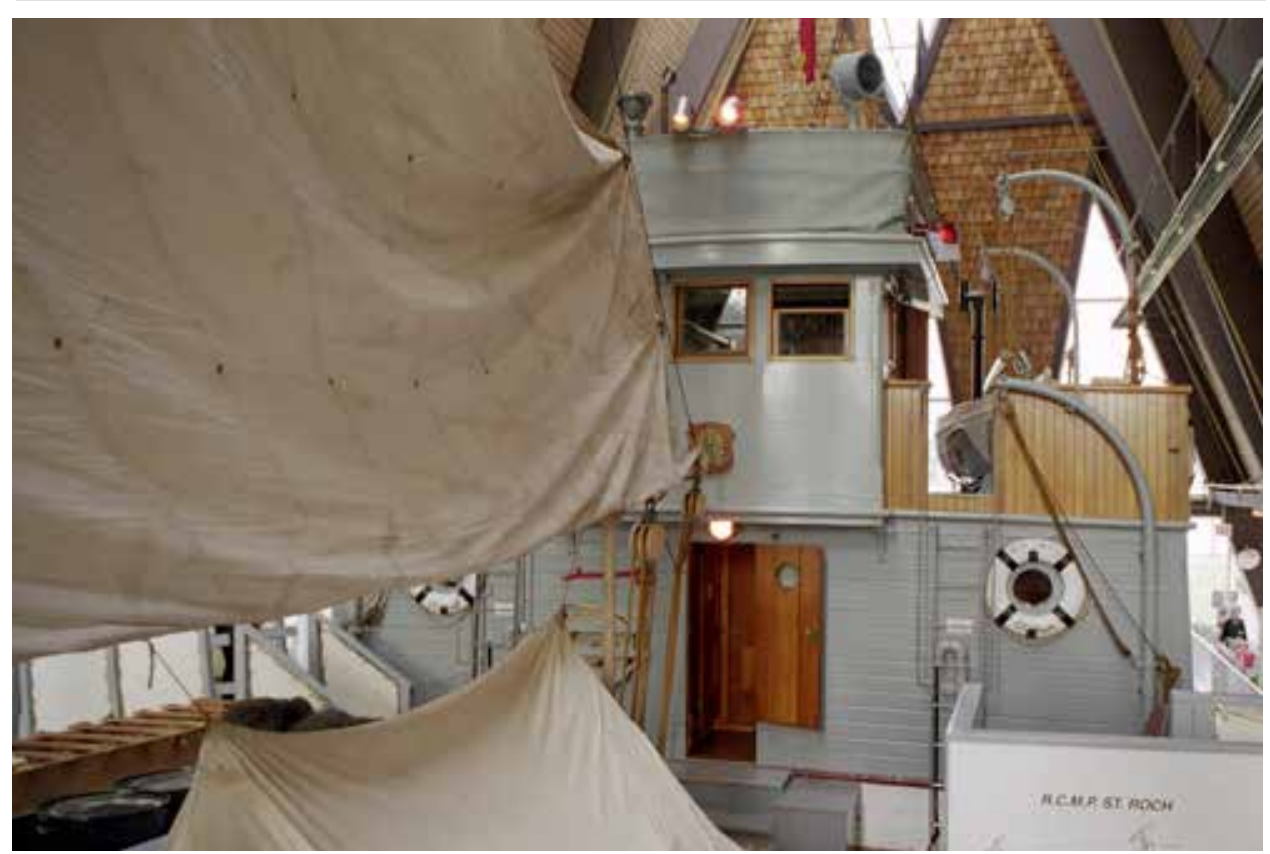

The St. Roch at the Vancouver Maritime Museum (lan Abbott, Flickr.com)

In future partition of northern lands, a country whose possession today goes up to the Arctic regions, will have a right, or should have a right, or has a right to all the lands that are to be found in the waters between a line extending from its eastern extremity north, and another line extending from the western extremity north. All the lands between the two lines up to the north pole should belong and do belong to the country whose territory abuts up there. ${ }^{12}$

Such a system would allow the Canadian government to insist that "from 141 to 60 degrees west we are on Canadian territory.... No foreigner has a right to go and hoist a flag on it up to the north pole." 13 While the Canadian government never officially entrenched the sector principle in federal statute, it remained an important component of Ottawa's Arctic sovereignty strategy in the decades that followed.

The Canadian government continued to utilize the newly-renamed Royal Canadian Mounted Police (RCMP) to secure its sovereignty in the years following the First World War. The police presence grew in the western Arctic, with new posts at Tree River, Aklavik, Cambridge Bay, and Kugluktuk. When Ottawa thought that Denmark might challenge Canada's sovereignty over Ellesmere Island in the

${ }^{12}$ Quoted in Ivan Head, "Canadian Claims to Territorial Sovereignty in the Arctic Regions," McGill Law Journal 9 (1963), 203-4, and in Donat Pharand, Canada's Arctic Waters in International Law (Cambridge: Cambridge University Press, 1988), 9-10.

${ }_{13}$ Canada, Senate Debates, 20 February 1907, 271. 
early 1920s, it led to a flurry of legal appraisals emphasizing "the need for 'acts of occupation' even on remote and uninhabited northern islands like Ellesmere." 14 Consequently, when the Liberal government of William Lyon Mackenzie King came to power at the end of 1921, it instituted an annual ship patrol in the Eastern Arctic and started to expand the RCMP's permanent presence on the Arctic islands, beginning with new posts at Pond Inlet on Baffin Island and Craig Harbour on Ellesmere Island in 1922 - the first police presence in the Qikiqtaaluk Region. Additional posts followed at Pangnirtung in 1923 and Dundas Harbour, Devon Island in $1924 .^{15}$

Despite the government's "acts of occupation," Ottawa realized in 1925 that the United States did not accept Canada's sovereignty over the entire Arctic archipelago. By this point, Washington had adopted the Hughes Doctrine, which demanded settlement and use of polar lands as a requisite of territorial acquisition. ${ }^{16}$ The State Department did not accept "that such occupation has been effected by Canada in some of the islands," particularly the uninhabited ones north of Parry Channel. ${ }^{17}$ The matter became a concern in the spring of 1925, when the US government decided to sponsor an expedition led by Donald MacMillan and Richard Byrd that intended to aerially explore the area between Canada's northernmost islands and the North Pole that summer, using bases on Axel Heiberg and Ellesmere Island. ${ }^{18}$ The State Department had not consulted with Ottawa on this mission or applied for any permissions or permits - although it also chose not to explicitly and publicly challenge Canada's claim.

In response, Ottawa established the Northern Advisory Board to discuss the implications of the American expedition on Canada's sovereignty and lay out possible policy alternatives. After careful deliberation, the board decided to continue relying on the internationally accepted method of effective occupation to strengthen Canada's claims, supported by a government announcement of a

14 Janice Cavell and Jeff Noakes, Acts of Occupation: Canada and Arctic Sovereignty, 1918-25 (Vancouver: UBC Press, 2010), 6. Cavell and Noakes argue that, in reality, Rasmussen and the Danish government never denied Canadian sovereignty, and they allege that Stefansson stoked sovereignty concerns in the hopes that he would be rewarded with a new expedition to occupy the northern islands. See also Smith, Historical and Legal Study, 215-266.

15 For more on Canadian government activity in the Arctic in the early 1920s see, Morrison, Showing the Flag; Janice Cavell, "The Origins of Canada's First Eastern Arctic Patrol, 1919-1922," Polar Record 45, no. 233 (2009), 97-112; Peter Schledermann, "The Muskox Patrol: High Arctic Sovereignty Revisited," Arctic 58, no. 1 (2003), 101-109; and Smith, Historical and Legal Study, 341-67.

${ }^{16}$ P. Whitney Lackenbauer and Peter Kikkert, "The Dog in the Manger - and Letting Sleeping Dogs Lie: The United States, Canada and the Sector Principle, 1924-1955,"' in The Arctic Ocean: Essays in Honour of Donat Pharand, ed. Suzanne Lalonde and Ted McDorman (Leiden: Brill, 2014), 216239.

17 Suggested Draft Note to the British Embassy, Department of State, Division of Western European Affairs, 16 September 1925, US National Archives and Records Administration (NARA), RG 59, CDF 1910-1929, Box 7156, File 800.014.

18 John H. Bryant and Harold N. Cones, Dangerous Crossings: The First Modern Polar Expedition, 1925 (Annapolis: Naval Institute Press, 2000). 
sector claim in the House of Commons. ${ }^{19}$ On 1 June 1925, Minister of the Interior Charles Stewart stood in the House of Commons and claimed all the land between Canada's coast "right up to the North Pole." 20 Once again, Ottawa turned to the RCMP to safeguard its sovereignty in the Arctic, constructing new posts on Ellesmere Island's Bache Peninsula in 1926 and another at Lake Harbour in 1927. From their posts, RCMP officers sought to extend Canada's occupation and control with long sled patrols that covered much of the high Arctic islands - including Inspector Joy's epic 1700-mile trek from Devon Island to Melville Island.

With growing concerns in Ottawa about Canada's sovereignty over the Arctic Islands, the RCMP considered another measure to expand its activities in the region - a small schooner that could resupply the police posts, allow for patrols in the summer months, and sail wherever a stronger government presence might be required. "It was a demonstration of sovereignty; fixed during the winter and mobile during the short navigation season," historian William Morrison explains. This ship represented "the answer to the problem posed as early as 1900 by [NWMP] Comptroller Frederick White- how to make the police on the Arctic coast more mobile and thus more effective?"21 The Minister of Justice concurred with the plan in 1925 and the government let a construction contract to the Burrard Dry Dock Company of North Vancouver in 1927 to build the vessel. It was ready the following year and named St. Roch - "guardian of the poor" - after a parish in the constituency of justice minister Ernest Lapointe. Gordon Smith described:

The St. Roch was 104 feet in length, 25 feet in beam, with draft when loaded of $12 \frac{1}{2}$ feet and net tonnage of 80 tons. Designed especially for Arctic service, she had a saucer-shaped cross section, which enabled her to rise above the crushing pressure of surrounding ice rather than being squeezed in it. For greater strength, the ship was built solidly of heavy Douglas fir, with a complete outside sheeting of Australian ironbark. She had schooner rigging and was equipped with a 150-horsepower diesel engine. ${ }^{22}$

The rounded hull meant that the ship rocked and heaved heavily in open seas, but what it lacked in comfort it compensated for in strength and dependability.

During the ship's maiden voyage to the Arctic in 1928, Henry Asbjørn Larsen was thrust into a leadership role when the skipper (Captain William Hugh Gillen) left the ship at Herschel Island in late August. Born in the village of Fredrikstad on

\footnotetext{
${ }^{19}$ For a further explanation of the important role that James White played in Canada's legal strategy, see Cavell and Noakes, Acts of Occupation, 75, 221, 227.

${ }^{20}$ Canada, House of Commons Debates, 1 June 1925, 3773.

${ }^{21}$ Morrison, Showing the Flag, 175-176.

22 Smith, Historical and Legal Study, 371. See also Henry A. Larsen, The Big Ship (Toronto: McClelland and Stewart, 1967), 36-39; and James P. Delgado, Arctic Workhorse: The RCMP Schooner St. Roch (Vancouver: Touch Wood Editions, 2003), 53-63.
} 
the east coast of Norway's Oslo Fjord in 1899, Larsen had served in merchant ships for most of his life and even spent some time in the Canadian Arctic. ${ }^{23}$ Now, under Larsen's command, St. Roch spent twelve summers and four winters patrolling the Western Canadian Arctic and resupplying RCMP detachments along the Arctic coastlines. ${ }^{24}$ According to his daughter Doreen Larsen Reidel, "these voyages were undertaken largely through uncharted waters, without the benefit of sonar, aerial ice reconnaissance, regular radio contact and relying on navigational methods dating back hundreds of years." ${ }^{25}$ Larsen explained in more detail the myriad government tasks performed by St. Roch in addition to its formal "policing" responsibilities:

Firstly, to uphold and enforce Canada's sovereignty of her Arctic Islands; to act as administrators for the North-West Territories Council; maintaining game laws; making general checkups of Eskimos' living conditions; compiling Vital Statistics; authorizing the issuing of rations for the destitute aged and infirm Eskimos; taking of census; settling of any disputes which might arise; conveying children to and from the residential schools at Aklavik; and transferring sick Eskimos for treatment and hospitalization at Aklavik. Sometimes we assist in securing suitable Eskimos, with their families, who we transport from the Coronation Gulf area to the Mackenzie River Delta to learn to herd and look after the reindeer herd provided by the Canadian Government for the Eskimos in that area. ${ }^{26}$

St. Roch continued to fulfill these roles even as the Great Depression necessitated the closure of certain RCMP posts in the North, including the Bache Peninsula and Dundas Harbour detachments. ${ }^{27}$

In response to Canada's weakened efforts at occupation in the Arctic archipelago, in 1936 T.L. Cory, solicitor of Canada's Northwest Territories Branch of the Department of the Interior, furnished a legal appraisal of Canada's position that read like a call to action. He worried about the strength of Canada's title and wanted the government to invest more in its Arctic. Cory's appraisal highlighted the American demand for "rigorous occupation," and accordingly emphasized the need for a stronger physical presence in the region. Despite the placement of several RCMP posts along the eastern fringe of Canada's "vast Arctic claim," he worried about "all the unoccupied islands lying to the west and within the Canadian Arctic

${ }^{23}$ Larsen, Big Ship, 1-2, 27, 34-35.

${ }^{24}$ A.E. Porsild, "Henry Asbjorn Larsen (1899-1964)," Arctic 18, no.1 (1965), 67; Larsen, North-West Passage, 7.

${ }^{25}$ Doreen Larsen Riedel, quoted in Ship St. Roch Commemorative Association (SSRCA), St. Roch: RCMP Patrol Vessel St. Roch Commemorative (Dartmouth, 2007), 5.

${ }^{26}$ Larsen, North-West Passage, 8-9.

27 Report of a Conversation on 6 February 1940, with Major McKeand of the Department of Mines and Resources, Memorandum from Third Secretary, Department of External Affairs, to UnderSecretary of State for External Affairs, 6 February 1940, document 547 in Cavell, DCER: Arctic, 819-821. 
sector" - such as Melville Island. He envisioned parties "empowered to administer the laws of Canada" establishing substations across the Archipelago, supported by a fleet of Arctic capable airplanes, and capable of carrying "active jurisdiction into many of our outlying Western islands." ${ }^{28}$ In the end, the cost proved prohibitive, and Ottawa barely considered the plan at the time. Cory's ideas, however, ultimately would have an impact on St. Roch and its 1944 voyage through the Passage.

\section{St. Roch and the First West-East Transit of the Northwest Passage, 1940- 1942}

At the end of the 1930s, Larsen, St. Roch, and the scattered RCMP posts that remained open through the Great Depression, continued to function as the cornerstone of Canada's sovereignty in the Arctic. ${ }^{29}$ When the Second World War broke out, however, St. Roch was recalled to Vancouver to be assigned other duties. The war had prompted the closure of the Craig Harbour RCMP post in 1940, which left no official government presence in the islands north of Parry Channel - the area of the Archipelago where the US had refused to acknowledge Canada's sovereignty. How would the abandonment of this post for the duration of the war affect Canada's claim? Max Wershof, a young lawyer at External Affairs, concluded that,

it seems to me that even a temporary abandonment of the Craig Harbour post must weaken - though it will not nullify - Canada's claim, not only to Ellesmere Island but also to all the islands lying north of Viscount Melville Sound and Lancaster Sound - unless a suitable substitute for the Craig Harbour post is provided. The islands lying north of the aforementioned line may, I think, be considered as a group. Craig Harbour is the only post in this area. If it is abandoned, without a substitute, there will be no one physically present in the area to symbolize effective occupation.

Wershof, however, offered a potential solution. He cited William Edward Hall's Treatise on International Law to note that abandonment of territorial title does not happen immediately in places where a state had sustained an occupation for "some time." If the "[abandonment] has been voluntary, the title of the occupant may be kept alive by acts, such as the assertion of claim by inscriptions, which would be insufficient to confirm the mere act of taking possession." In Wershof's opinion, temporary visits and cairns could sustain Canada's title until a permanent occupation was restored. ${ }^{30}$

\footnotetext{
28 T.L. Cory, compiled for the Northwest Territories Council, British Sovereignty in the Arctic, 3 June 1936, Library and Archives Canada (LAC), RG 25, Vol. 4253, File 9057-40 pt. 4. See also Laurent Beaudry, Under-Secretary of State for External Affairs to T.L. Cory, 20 March 1937, LAC, RG 25, Vol. 1658, File 1933-253.

${ }^{29}$ Cavell, "Introduction," in DCER: Arctic, xxxii.

${ }^{30}$ Memorandum from Third Secretary, Department of External Affairs, to Under-Secretary of State
} 
Historian Janice Cavell criticizes Wershof, T.L. Cory, and other External Affairs officials who doubted the strength of Canada's sovereignty in the 1940s, suggesting that they demonstrated "little knowledge of international law on the polar regions" and ignored or misunderstood the impact of the 1933 Eastern Greenland decision on territorial claims in the Arctic. In the dispute between Denmark and Norway over Greenland, the Permanent Court of International Justice (PCIJ) had accepted a modest threshold for effective occupation in the polar regions. Cavell argues that Canadian officials who had grappled with the "Arctic policy regime" in the 1920s, such as Secretary of State for External Affairs O.D. Skelton, understood the impact of the Eastern Greenland decision and recognized that Canada's title was strong. Skelton passed away in 1941, however, before he could write a comprehensive treatise on Canada's sovereignty in the Arctic, and Cavell alleges that his younger colleagues like Wershof floundered without his "insider knowledge." 31

In her critique, Cavell overestimates the clarity on the rules of territorial acquisition that existed at the time and underestimates the confusion that permeated the legal landscape of the polar regions. By the 1940s, the doctrine of effective occupation, the most important justification for territorial acquisition, remained unclear and open to interpretation. "The word 'occupation' itself is... a legal term of art," legal scholar Humphrey Waldock explained in 1948. "It is the Latin occupatio meaning appropriation, not occupation in its sense of 'settling on'...it means, in international law, the appropriation of sovereignty." ${ }^{32}$ Jurists and state officials, however, spilt much ink debating the level and kind of state activity the doctrine demanded - especially in the harsh environment of the polar regions. ${ }^{33}$ How much uninhabited or sparsely populated territory could a state claim to occupy through a settlement or an administrative post? Could Canada's control be extended to all of the islands in the northern half of the Archipelago through an occupied police post on Ellesmere Island? How continuous did an occupation have to be to maintain a state's territorial rights? What impact might technological innovations (such as such as long-range aircraft, mechanical vehicles, advanced icebreakers, and stations that allowed people to overwinter relatively comfortably in the harshest polar regions) have on the requirements of occupation?

Like Cavell, historians and lawyers often point to the Palmas Island (1928), Clipperton Island (1931), and Eastern Greenland (1933) cases - which all dealt

\footnotetext{
for External Affairs, 6 February 1940, in Cavell, DCER: Arctic, document 547, 819-821; Report of a Conversation on 6 February 1940, with Major McKeand of the Department of Mines and Resources, Memorandum from Third Secretary, Department of External Affairs, to Under-Secretary of State for External Affairs, 6 February 1940, in Ibid, document 547, 819-821

31 Skelton did not accept Wershof's opinion that the closure of the Craig Harbour post for the duration of the war would "seriously weaken Canada's claim." Cavell, "Introduction," in DCER: Arctic, xxxiii, note 41 .

${ }^{32}$ C.H.M. Waldock, "Disputed Sovereignty in the Falkland Islands Dependencies," British Yearbook of International Law 25 (1948), 317 fn. 2.

33 See, for example, Martti Koskenniemi, The Gentle Civilizer of Nations: The Rise and Fall of International Law, 1870-1960 (Cambridge: Cambridge University Press, 2001), 121-155.
} 
with state title over uninhabited, or sparsely populated territory - as pivotal decisions that brought immediate clarity to the international law of territorial acquisition. ${ }^{34}$ Certainly, many international legal experts recognized the potential impact of these cases on polar territorial claims, particularly the PCIJ's decision in the Eastern Greenland case. ${ }^{35}$ For the majority of practitioners, however, the judicial nature of polar sovereignty remained ambiguous. From its release in 1933, various legal experts questioned the value of the Eastern Greenland decision as a precedent. Commentators underlined the volume of variables that complicated the case: the role played by foreign recognition; the length of time involved; the careful balancing of legal values carried out by the court; the court's failure to lay out the acts required to create and maintain a right to sovereignty; and the existence of a dissenting opinion and separate opinions in the ruling that could have played an important role in future cases..$^{36}$ In light of these factors, professor of international law and former solicitor of the State Department Charles Cheney Hyde concluded that the decision "may perhaps be deemed to lack the significance otherwise to be assigned to it as an enunciation of legal principle concerning" the acquisition of territorial sovereignty. ${ }^{37}$ No one could predict with certainty how the arguments, conclusions, and opinions of the Eastern Greenland decision would be applied to future polar disputes. State officials involved in researching polar claims recognized the shades of grey that continued to surround the requirements of effective occupation and the rules of territorial acquisition. In 1944, a Canadian External Affairs report captured the essence of the problem when it explained that, "there may be some doubt whether Canada is actually extending enough jurisdiction throughout lands already discovered to make her claim to those territories unquestionable.... Precise information as to what constitutes 'control and administration' is scarce." 38

In short, the concerns that many Canadian officials had about the strengths of their country's sovereignty over the northern islands of the Arctic archipelago are understandable when viewed in the international legal context of the 1940s.

\footnotetext{
${ }^{34}$ For such analysis of the Eastern Greenland case, see, for example, Smith, Historical and Legal Study, 313-20; Cavell and Noakes, Acts of Occupation, 246-247, 260; and Grant, Polar Imperative, 193 and 242.

${ }^{35}$ See, for example, J.S. Reeves, "George V Land," American Journal of International Law 28, no. 1 (Jan., 1934), 119; and Anonymous, "The Legal Status of Eastern Greenland," Geographical Journal 82, no. 2 (1933), 151-156. For examples of state legal appraisals that analyze and assess these three cases, see: Law Officers of the Foreign Office and Colonial Office, Paper B on the Legal Authorities, 12 January 1947, United Kingdom National Archives (NA), FO 371/61288; and E.R. Hopkins, Legal Adviser for External Affairs, Legal Aspects of Sovereignty in the Canadian Arctic, 22 January 1949, LAC, RG 2, Vol. 122, File A-25.

36 Judge Dionisio Anzilotti offered the dissenting opinion, while Walther Schücking and Wang Chung-hui offered the separate opinions.

${ }^{37}$ C.C. Hyde, "Acquisition of Sovereignty over Polar Areas," Iowa Law Review 19, no. 293 (193334), 287, n. 3.

${ }^{38}$ J.R.B. Chaput, Memorandum for the Legal Adviser, Proposed Voyage of the RCMP in the Arctic, 21 May 1944, LAC, RG 85, vol. 268, file 1003-6-1.
} 
Legal ambiguities at the time precluded them from any assurance that Canada had done enough to secure its title to all of the Arctic islands. These considerations played a role in the government's decision to send St. Roch through the Northwest Passage in spring 1940. Other factors also inspired the decision to move St. Roch secretly from Vancouver to the eastern Arctic: the need to defend Greenland in the face of increased German activity in the North Atlantic, concern over the security of the island's cryolite mines (crucial in the production of aluminum), and the possibility that a Canadian occupation force might have to be deployed, supplied, and supported. ${ }^{39}$ Still, Larsen believed that sovereignty represented the main driver. "It was a great moment for me," he later explained. "Canada was at War and the Government realizing the need to demonstrate sovereignty over the Arctic Islands, was continuing to entrust the discharge of that responsibility to the Royal Canadian Mounted Police as it had done for decades, ever since the first detachment was built at Cape Fullerton on the West side of Hudson Bay 1903." ${ }^{40}$ Larsen was ordered to sail St. Roch through the northerly route of the Northwest Passage, utilizing Prince of Wales Strait and Viscount Melville Sound, which would have allowed them to visit some of the unoccupied islands in the northern half of the Archipelago - just as Wershof had advised in his appraisal. ${ }^{41}$

Heading out in the summer of 1940, Larsen ran into heavy ice conditions that slowed his progress and delayed his resupply of the western Arctic RCMP posts. Battling through heavy ice, St. Roch's crew wintered at Walker Bay on the west coast of Victoria Island. The ship resumed its voyage on 31 July 1941, but, once again facing heavy ice conditions, Larsen decided that the northern route was impractical and adjusted his plans to take the route charted by Amundsen in 1903-05, south of King William Island and through Bellot Strait before heading into Baffin Bay. Ice halted the crew's progress at Pasley Bay on the west coast of Boothia Peninsula, where they were frozen in until August 1942. Rather than sitting idle during the long winters, members of the nine-man $\mathrm{crew}^{42}$ embarked on lengthy sled patrols across the adjacent islands. In early August 1942, the crew managed to extract St. Roch from Pasley Bay and head north, pushing through Bellot Strait, despite ice barriers, strong currents, and whirlpools. The ship then proceeded up Prince Regent Inlet to Lancaster Sound, entered Navy Board Inlet, and on 6 September arrived at Pond Inlet on the northeast tip of Baffin Island. On

\footnotetext{
${ }^{39}$ Grant, "Why the St. Roch?", 85; Smith, Historical and Legal Study of Sovereignty, 376. See also Sgt. F. S. Farrar, "Arctic Assignment: The Story of the St. Roch," in Great Stories of Canada Series, ed. B. Bonnezen (Toronto: Macmillan, 1955), 21, 24, 34, 36.

${ }_{40}$ Larsen autobiography manuscript, 745-46, quoted in Smith, Historical and Legal Study, 372-73. See also Larsen, Big Ship, 140-42.

${ }^{41}$ Larsen to O.C. "G” Division, RCMP, 12 November 1940, LAC, RG 18, vol. 8139, file "Patrols and Mileage of St. Roch Detachment."

${ }^{42}$ In his 12 November 1940 report to the Officer Commanding "G' Division, Larsen's listed his crew as: F.S. Farrar, first mate; M.F. Foster, chief engineer; J. Friederick; B.C. Hadley; P.G. Hunt; W.J. Parry; A.J. Chartrand; and J.M. Monette. Constable Albert "Frenchy" Chartrand, a popular member of the crew with extensive Arctic experience, died from a heart attack in February 1942.
} 


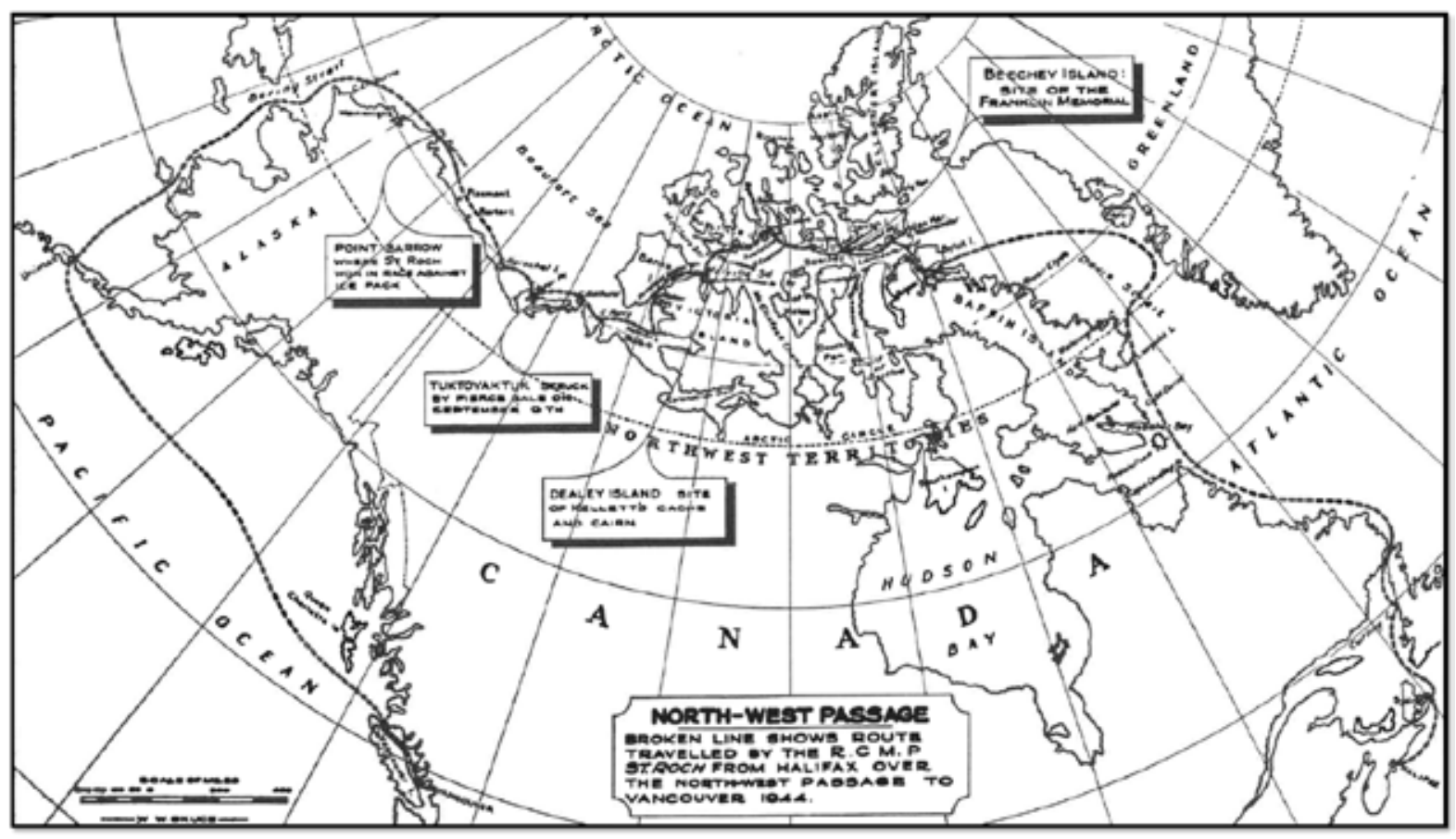

11 November, a naval escort took St. Roch into Halifax Harbour, thus completing the twenty-eight month voyage and the first transit of the Northwest Passage from west to east. "It had not been an easy trip," Larsen noted in a typically understated quip, adding that "without hesitation I would say that most ships encountering the conditions we faced would have failed." 43

\section{St. Roch and the Northerly Route}

Despite the accomplishment of Larsen and his crew, concerns within Ottawa about Canada's sovereignty in the Arctic continued to intensify as the war went on. By the time St. Roch returned to Halifax in 1942, the exigencies of continental defence had started to transform the Canadian North. In the Northwest, the Americans assisted in the completion of the Northwest Staging Route and constructed the Alcan (Alaska Highway) and the Canol pipline, bringing an influx of 40,000 American personnel into the region. In the Northeast, ambitious plans for the Crimson Route, an alternate path for ferrying planes and materials to Britain, involved installations at Churchill, Manitoba; Southampton Island in Hudson Bay; Fort Chimo (Kuujjuaq); Frobisher Bay (Iqaluit); Padloping Island, Merchants Bay; and other northern sites. Historians have pointed out the local and national controversies that accompanied these northern projects, and Prime Minister King, paranoid that American developments, conducted in the name of military security, would undermine Canada's sovereignty and control, took action to reassert

${ }^{43}$ Quoted in Delgado, Arctic Workhorse, 38. 
Ottawa's authority on the ground in the North in 1943 and $1944 .^{44}$

Although the northern islands of the Arctic archipelago where Ottawa had the most concern about its territorial title were untouched by these wartime projects, what if the Americans decided that they wanted to build airfields on these islands? By the fall of 1943, rumours had started to circulate within the Canadian government about the American desire to build defence and aviation infrastructure in the high Arctic. ${ }^{45}$ When Brian Roberts, an Antarctic expert with the British Foreign Office, visited Ottawa at that time, his Canadian peers worriedly told him about future American "pretentions in the Arctic." 46 If the Americans wanted to expand their efforts into the high Arctic, would they ask permission? Recent history and the Hughes Doctrine suggested they would not. In his 1940 report on the Craig Harbour closure, Wershof had noted that "a weakening of Canada's legal claim may not be important if the Government is confident that no serious challenge will ever be forthcoming." With American interest in the high Arctic growing, such a challenge seemed more plausible than ever.

In early 1944, a series of government officials highlighted their concern over the status of Canada's Arctic sovereignty. J.G. Wright, a member of the Northwest Territories Administration, argued that the far and western islands, which had never been home to a permanent RCMP presence, were administered "mostly in theory" and advised that Ottawa establish weather and scientific stations in the region to strengthen Canada's claim. ${ }^{47}$ An assessment prepared by J.R.B. Chaput for John Read, the External Affairs' legal adviser, also advised that a Canadian expedition would do much to extend the government's administration and control the region. ${ }^{48}$ R.A. Gibson, deputy commissioner of the Northwest Territories, responded to a media report raising the issue of Arctic sovereignty by suggesting that the government extend the patrols of the RCMP in the Arctic, either using St. Roch or the airplanes of the RCAF. ${ }^{49}$ Gibson's suggestion provided the initial push that began the planning for St. Roch's 1944 voyage.

At this point, Canadian officials received further impetus to take action in the Arctic when they learned what Britain was doing to protect its territorial claims

\footnotetext{
${ }^{44}$ For overviews on wartime developments, see Shelagh Grant, Sovereignty or Security?: Government Policy in the Canadian North, 1936-1950 (Vancouver: UBC Press, 1988), and Ken Coates, P. Whitney Lackenbauer, William Morrison, and Greg Poelzer, Arctic Front: Defending Canada in the Far North (Toronto: Thomas Allen, 2008).

${ }^{45}$ Minutes and Documents of the C.W.C., Doc. No. 704, memo, Heeney to C.W.C., 3 February, 1944; and Minutes of meeting of Canadian officials in Ottawa, 26 January 1944, LAC, RG 85, Vol. 823, File 7140; Malcolm Macdonald, Note on Developments in North-Western Canada, 6 April 1943, NA, DO 35/1645.

${ }^{46}$ G.E. Boyd Shannon, Note, 17 November 1943, NA, DO 35/1423; and Brian Roberts, Journal of Visit to the United States and Canada, August-November 1943, SPRI, MS 1308/5 BJ, Roberts, Brian.

47 Wright to Gibson, 9 February 1944, LAC, RG 85, Vol. 823, File 7140.

${ }^{48}$ Chaput, Memorandum for the Legal Adviser, 21 May 1944.

49 Letter from Deputy Commissioner of Northwest Territories to Commissioner, Royal Canadian Mounted Police, 27 January 1944, in Cavell, DCER: Arctic, document 570, 849.
} 
in the Antarctic. ${ }^{50}$ Ottawa had long looked to British legal assessments regarding their sovereignty over the Falkland Islands Dependencies (FID), encompassing a slice of the Antarctic continent, South Georgia, South Sandwich Islands, the South Shetlands, and South Orkneys) for guidance and confirmation of its own approaches and policies in the Arctic. Since the beginning of the century, the British had adopted a version of effective occupation in the polar regions that was less stringent than Ottawa's. In the harsh polar environment, they insisted that control could consist of the occasional visit by state officials, administrative acts, legislation, and whatever level of control was required over the points of access to a polar interior or hinterland. ${ }^{51}$ Early in the war, however, the United States Antarctic Service Expedition had set up camps in the FID, and Chile and Argentina had challenged Britain's title with overlapping claims of their own. These developments, technological innovations, and the legal position of the US, led Foreign Office legal adviser William Eric Beckett to assert that the requirements of effective occupation in the polar regions had become more onerous, demanding continuous "physical occupation and use." 52 As the British explained to the Canadians in 1943, "we have made little use of the islands [in the Antarctic] and our legal position is therefore becoming weaker." 53

During the Antarctic summer of 1942-1943, Ottawa learned that London had dispatched HMS Carnavon Castle on an "administrative tour" of the FID on the pretext of countering Axis raider activity. The ship's crew obliterated sovereignty markers left in the South Shetlands by previous Argentine expeditions and replaced them with British emblems to mark their presence. In the early 1944, the British told the Canadians about the recently launched Operation Tabarin an expedition to establish permanent bases in the FID, from which parties could conduct scientific research and surveys, and provide a source of administration. ${ }^{54}$ As historian Peter Beck has observed, the British initiatives in the Antarctic

\footnotetext{
50 N. Robertson, Secretary of State for External Affairs, to the Canadian Minister to Argentina, 23 February 1944, LAC, RG 25, vol. 4524, file 9090-A-40, pt. 1.

51 Brian Roberts, Journal of Visit to the United States and Canada, August-November 1943, Scott Polar Research Institute, MS 1308/5 BJ, Roberts, Brian.

${ }^{52}$ W.E. Beckett, Note, 16 September 1942, NA, FO 371/30313. See also Statement by Foreign Office Legal Adviser on the Necessity of Physical Occupation as a Means of Securing Sovereignty in the Polar Regions, Polar Committee Meeting, 31 October 1946, LAC, RG 25, Vol. 3347, File 9092-A-40. 53 N. Robertson, Secretary of State for External Affairs, to the Canadian Minister to Argentina, 23 February 1943, LAC, RG 25, vol. 4524, file 9090-A-40, pt. 1.

54 Secretary of State for Dominion Affairs to the Under Secretary of State for External Affairs, 6 May 1944, LAC, RG 25, vol. 4524, file 9090-A-40, pt. 1. The history of Operation Tabarin has been well covered. See, for example, John R. Dudeney and David Walton, "From Scotia to 'Operation Tabarin': developing British policy for Antarctica,” Polar Record 48 (247 (2002), 342-360; Vivian Fuchs, Of Ice and Men: The Story of the British Antarctic Survey, 1943-1973 (Shropshire: Anthony Nelson, 1982); Stephen Haddelsey, Operation Tabarin: Britain's Secret Wartime Expedition to Antarctica, 1944-1946 (Stroud: History Press, 2014), and Andrew Taylor, Two Years Below the Horn: A Canadian's Experiences in Antarctica, 1944-46, eds. Daniel Heidt and P. Whitney Lackenbauer (Winnipeg: University of Manitoba Press, 2017).
} 
influenced how Canadians viewed their position in the Arctic during the war. ${ }^{55}$ Certainly, the kinds of activities conducted by the British and their new approach to polar sovereignty would have been fresh in the mind of Canadian officials as they prepared to send St. Roch north again in 1944.

Ongoing concern over the strength of Canada's claim to the northern half of the archipelago, worry over American intentions, and British actions in the Antarctic all spurred on and shaped St. Roch's attempt on the Northwest Passage. Larsen was again ordered to take the Passage's northern route and visit the western islands north of Parry Channel that T.L. Cory, Max Wershof, and J.G. Wright had expressed concern about, including Cornwallis, Bathurst, and Melville islands. J.R.B. Chaput advised that Larsen take no action that could be construed as Canada taking possession of new land within the archipelago - the country had already claimed all of it and any suggestion to the contrary might encourage rival claims. Rather than taking possession, Larsen and his crew would leave "suitable records at all points" visited, visible demonstrations that they had ventured to the northern half of the archipelago to extend Canada's administration and control over the region. If ice conditions were poor, Larsen was ordered to overwinter at Winter Harbour, from which "patrols by dog team would visit various Arctic Islands within a radius of two hundred miles." During its transit, St. Roch would also collect topographical information and make other scientific observations, and investigate the possibilities of reopening the Craig Harbour and Dundas Harbour RCMP posts in the near future, and establishing a new detachment at Winter Harbour. While in the southern waters of the archipelago, the ship would fulfill its primary function of resupplying RCMP posts and administering Inuit. ${ }^{56}$

Larsen and St. Roch prepared to head northwards once again in the name of Canada's Arctic sovereignty. Since their arrival in Halifax in 1942, Larsen and seven other crew members had been awarded the Polar Medal, ${ }^{57}$ and the ship had sailed north again in July 1943 to provision detachments along the Labrador and eastern Baffin Island coasts before returning to Halifax that October. The following winter it underwent extensive refit and had a 300-horsepower engine installed at Lunenburg Foundry \& Engineering. When he received his orders to head north in the summer of 1944, all but two of Larsen's crew from 1940-42 had taken up other assignments, so he quickly found replacements. Now expanded to thirteen members, the crew included a mix of seasoned Arctic hands and two young Newfoundland seamen with no previous experience. "Well here we are

\footnotetext{
55 Peter Beck, “Through Arctic Eyes: Canada and Antarctica, 1945-62," Arctic 48:2 (1995), 138-140.

${ }^{56}$ Chaput, Memorandum for the Legal Adviser, 21 May 1944; Under-Secretary of State for External Affairs to Director, Lands, Parks and Forests Branch, Department of Mines and Resources, 1 June 1944, LAC, RG 25, Vol. 3347, File 9061-A-40; D.J. Martin, Supt. Commanding G Division to the Officer Commanding, RCMP, H Division, Halifax, N.S., 9 May 1944, LAC, RG 85, vol. 268, file 1003-6-1; Commissioner S.T. Wood, West Through the North West Passage, 20 October 1944, LAC, RG 85, vol. 268, file 1003-6-1; R.A. Gibson to the Commissioner, RCMP, 19 July 1944, LAC, RG 85, vol. 268, file 1003-6-1.

57 "R.C.M.P. Who Made Perilous Northern Passage Get Honors," Ottawa Journal, 1 January 1943, 3.
} 
again not quite ready for the great adventure of again trying to make the North West Passage," he wrote in his diary. "We must do all in our power ... to uphold Canada's claim to these valuable islands and bulwark for our northern frontiers. Canada and its people have adopted me as one of their own sons, and it's up to me to be worthy of such an honour." 58

Although the ship had to divert to Sydney for minor repairs soon after leaving Halifax on 22 July 1944, it overcame fog and ice to reach Pond Inlet on 12 August. Here Inuit guide Joe Panipakuttuk, several of his family members, and seventeen dogs embarked on this ship. ${ }^{59}$ Once they left Baffin Island on the 17th, Larsen and his crew focussed their attention on the islands of the northern archipelago, where there was no one to police or regulate. The ship sailed west, encountering foul weather as it travelled to Dundas Harour, Devon Island, where they investigated the "unoccupied" (not abandoned) police buildings that had stood empty since 1933. Next, Larsen and his crew ventured to Beechey Island, where they visited the graves of the deceased members of Franklin's ill-fated expedition buried there, the cenotaph erected to commemorate those who perished on Sir Edward Belcher's mission to find Franklin, the cache established in 1854 known as Northumberland House, and the remains of John Ross' old yacht Mary. Captain Bernier had also visited Beechey in 1906, and Larsen and his men located the cairn in which he left his records, attaching an account of their own visit. ${ }^{60}$

The ship ventured along Parry Channel, their initial attempts to land on Bathurst Island thwarted by thick pack ice moving quickly eastward, which ensnared them for some twenty miles. They eventually made it ashore at Cape Cockburn, but failed to locate the cairn left there by Bernier. With Bernier's cairn missing, Larsen wanted to be sure that he left a lasting sign of his expedition's presence, and "in a conspicuous place close to jutting rock about 300 feet high we built a cairn for our records." $"$ From Bathurst, the ship travelled to the north end of Byam Martin Island, where Larsen anchored, went ashore, built a cairn, and deposited a record of their visit. The weather had started to worsen, with wind, fog, sleet, and ice impeding the ship's movements. By 27 August, St. Roch made it to Dealy Island, and found the large cairn (a pile of stones, three barrels, and a tall spar) and storehouse built by Captain Henry Kellett when he overwintered there with HMS Resolute in 1852-1853. Here, Larsen and his men collected a few souvenirs, including tins that contained ox cheek soup made in London in 1850.

After their stop on Melville Island, Larsen and his crew turned into Viscount Melville Sound and headed for Prince of Wales Strait. Despite the expedition's

\footnotetext{
${ }^{58}$ Larsen quoted in Delgado, Arctic Workhorse, 40.

59 See Joe Panipakuttuk, "The Reminiscences of Joe Panipakuttuk." North 16 (January/February 1969), 10-17, reproduced in P. Whitney Lackenbauer and Shelagh Grant, eds., "The Adventurous Voyage”: St. Roch and the Northwest Passage, 1940-42 and 1944, Arctic Operational History Series, 7 (Antigonish: Mulroney Institute on Government, 2019).

${ }^{60}$ Larsen, "Return Voyage," 320.

${ }^{61}$ Larsen, North-West Passage, 41.
} 
rapid progress, it was not a smooth transit. On 31 August, in Prince of Wales Strait, they encountered the heaviest ice thus far and became locked in for a short period, near where Captains Parry and Bernier had been forced to turn around on previous attempts. "But there was no turning back for us," Larsen recounted in his autobiography, and he "began to negotiate the narrow passages between the gigantic floes of old blue ice from the Polar Sea itself." ${ }^{62}$ Overcoming ice, thick fog, mist, and heavy rain that temporarily set them off course, they navigated through the strait, reaching Walker Bay on 4 September. "We had gotten through the part of the Passage that no one else had; everybody was feeling pretty good," recalled crew member Stan McKenzie upon reaching this location where the ship had wintered in 1940-41. "The St. Roch rode at anchor as though catching her breath....and for the first time the northern route of the Northwest Passage had been traversed." ${ }^{63}$

Getting through in a single season, however, was not a preordained conclusion. The ship encountered heavy ice and hurricane-force winds along the coastline near Tuktoyaktuk and again faced the prospect of becoming frozen in. When the weather opened sufficiently on 17 September, Larsen pushed through for Herschel Island. There, the crew unloaded coal, fuel drums, and supplies, and set up the Panipakuttuk family in a house for the winter, before the ship departed hastily as the harbour began to freeze over. Overcoming heavy ice through to Point Barrow, the ship crossed through the Bering Strait on 27 September and arrived in Vancouver on 16 October. The ship had travelled 11,740 kilometres in eighty-six days, becoming the first vessel to complete the Passage in a single year and the first to transit it in both directions.

\section{Reflecting on the Accomplishment}

St. Roch's 1944 transit of the Northern route was a remarkable achievement, filled with risk and reward. Larsen and his crew were showered with accolades and honours for their historic achievement. "The newspapers were full of the story, and Larsen, his crew and his ship were hailed and honoured by the city [of Vancouver] and the nation," historian James Delgado observed. "For Henry Larsen, it meant a promotion to sub inspector and the award of the Patron's Gold Medal by the Royal Geographical Society. The Royal Geographical Society also elected Larsen a Fellow, as did the Royal Canadian Geographical Society and the Arctic Institute of North America." ${ }^{\prime 4}$ Members of his crew received the Polar Medal in recognition of their achievement - except the Inuk Joe Panipakuttuk who, with his family,

\footnotetext{
${ }^{62}$ Larsen, Big Ship, 189.

${ }^{63}$ McKenzie quoted in Ship St. Roch Commemorative Association, St. Roch (Halifax: Ship St. Roch Commemorative Association, 2007), 9.

${ }^{64}$ Delgado, Arctic Workhorse, 43. "As with my earlier promotions, this one too, I realized was due to my serving aboard the St. Roch in the Arctic, Larsen noted. "I felt a deep sense of gratitude." Henry Larsen, The Big Ship, 194.
} 
waited on Herschel Island for the ship's return before they made their trek home. ${ }^{65}$

For the Canadian government, one of the most important components of the entire expedition now began in earnest - getting the word about St. Roch's accomplishments. In the months that followed, Larsen published his official account, while the government provided information for additional stories in Maclean's and the Canadian Geographical Journal. ${ }^{66}$ While articles hailed the expedition's unprecedented transit of the Passage's northerly route, officials ensured that they also highlighted how many of the routes taken by St. Roch were the same as those previously taken by the Royal Navy and other Canadian vessels, and that past expeditions had visited and even temporarily occupied the same places visited by Larsen and his crew.${ }^{67}$ In his own accounts of the voyage, Larsen highlighted his use of British Admiralty charts, which he described as "marvellous" and "absolutely correct." ${ }^{68} \mathrm{He}$ also tied together the activities of the Royal Navy, with the efforts of the RCMP, and his own accomplishments on St. Roch:

It is true that many pioneers were defeated by the North; but I think it was because of the slow and cumbersome ships of those days, rather than the ice and inhospitableness of the land. Ships at that time were powered, in most cases, only by sail or inadequate steam engines, and when winter held them in a frozen berth there was often a crew of over a hundred to be fed. These men lived in cramped quarters for long tiresome months with little means of diversion and practically no opportunity to travel. Yet a few of the more intrepid set out on foot to explore and chart the country and claim it for the Empire. And this is the spirit we must not let die in Canada.

In their own way the Mounted Police are endeavouring to do their part. They have made long patrols which frequently surpassed those of many explorers. I have in mind the long overland journeys of ex-Asst. Commr. C. D. LaNauze, then inspector; ex-Asst. Commr. T. B. Caulkin, then sergeant major; the late Inspector Joy; the present-serving Sgt. Major H. W. Stallworthy and Cpl. R. W. Hamilton, and of many others....

But getting back to the early explorers. When I reached places which had known the footsteps of such men as Sir Edward Parry, Sir John Ross, Capt. Henry Kellett, Capt. Francis L. M'Clintock. Capt. Robert M'Clure, Sir John Franklin and others, I felt that I was on hallowed ground. I pictured them and their crews wintering in isolation and discomfort in crowded ships, optimistically waiting for favourable ice conditions; some of them perished, all risked death-to carry the proud flag of Britain into

\footnotetext{
${ }^{66}$ See J.G. Wight to Gibson, 4 December 1944, LAC, RG 85, vol. 268, file 1003-6-1. Lewis Robinson, "Conquest of the Northwest Passage by RCMP Schooner St. Roch," Canadian Geographical Journal 30, no. 2 (February 1945), 52-73; Bruce McLeod, “Nor'West Passage,” Maclean's 1 March 1945.

67 D.L. McKeand to Mr. Gibson, Bureau of Northwest Territories and Yukon Affairs, 2 December 1944, LAC, RG 85, vol. 268, file 1003-6-1.

68 Macdonald, W.E.G. "New St. Roch Record.” Scarlet and Gold 26 (1944), 17-24.
} 
new territory. When entering Erebus Bay last year I fancied I could see the tall majestic ships of Franklin who wintered there 99 yrs before. ${ }^{69}$

Connecting Larsen's 1944 voyage to these previous exploits not only placed the captain and his crew in a proud lineage of explorers, it also helped to confirm that the parts of the Arctic that he visited were hallowed Canadian ground. Government discussions and legal appraisals conducted in the lead-up to St. Roch's 1944 expedition, as well as the orders given to Larsen, indicated how Canadian officials understood Canada's Arctic sovereignty up to and during the Second World War. Faced with uncertainty about how secure Canada's claims to "effective occupation" actually were, St. Roch's wartime activities fulfilled Wershof's advice that "the title of the occupant may be kept alive by acts, such as the assertion of claim by inscriptions" until occupation could be renewed. On remote, uninhabited islands, Larsen and his crew visited cairns and memorials that Larsen called the "keystone of Canada's Arctic sovereignty" - visits that, in Larsen's view, were as important as the records and milestones set by St. Roch in transitting the Passage in a single-season by the Northern route. St. Roch proved a convenient vehicle to proactively demonstrate Canada's ongoing Arctic interest and capability, showing the world that Canada was still engaged in the region, just as Britain and its dominion had been for over a century.

\footnotetext{
${ }^{69}$ H.A. Larsen, “Our Return Voyage Through the North-west Passage,” Royal Canadian Mounted Police Quarterly 10:4 (April 1945), 318.
} 